\title{
Paracricetodontinae (Mammalia, Rodentia) from the late Eocene and early Oligocene of south-east Serbia
}

\author{
Andrew A. van de Weerd ${ }^{1} \cdot$ Hans de Bruijn ${ }^{1} \cdot{\text { Zoran } \text { Marković }^{2} \cdot \text { Wilma Wessels }}^{1}$
}

Received: 15 June 2017 /Revised: 16 October 2017 / Accepted: 18 December 2017 / Published online: 24 February 2018

(C) The Author(s) 2018. This article is an open access publication

\begin{abstract}
Three Paracricetodon species from the late Eocene locality Buštranje and the Early Oligocene localities Valniš, Strelac-1, -2, -3 and Raljin (south-east Serbia) are described; Paracricetodon dehmi Hrubesch, 1957 and two new species: Paracricetodon stojanovici and $P$. gracilis. A review of Paracricetodon species suggests that the species $P$. spectabilis, $P$. cadurcensis, $P$. dehmi, $P$. walgeri and $P$. wentgesi are primarily distinct in size. Paracricetodon kavakderensis and $P$. kodjayarmensis from Turkish Trace are considered junior synonyms of $P$. dehmi. The diversity and abundance of the Paracricetodontinae in the rodent assemblages from Serbia is not known from elsewhere and suggest that they underwent a radiation on the Serbian-Macedonian land area.
\end{abstract}

This is the fourth paper in the series "The Paleogene rodent faunas from south-east Serbia".

This article is registered in Zoobank under: urn:1sid:zoobank.org:pub:D97A7902-C079-40AF-ABAA1226FB525F54

Andrew A. van de Weerd

a.vandeweerd@uu.nl

Hans de Bruijn

HdBruijn@uu.nl

Zoran Marković

zoran.markovic@nhmbeo.rs

Wilma Wessels

w.wessels@uu.nl

1 Department of Earth Sciences, Utrecht University, Princetonlaan 8A, 3584 CB Utrecht, the Netherlands

2 Natural History Museum in Belgrade, Njegoševa 51, Belgrade 11000, Serbia
Keywords Rodentia · Paracricetodontinae - Late Eocene · Early Oligocene $\cdot$ South-east Serbia

\section{Introduction}

This study on the Paracricetodontinae is part of a series dealing with late Eocene and early Oligocene rodent faunas from seven localities in two basins in south-east Serbia. The first paper considers the geological setting, the description of the localities were the fossils have been collected, the methods and the general composition of the faunas (Bruijn et al. in press). This paper was followed by systematic descriptions of the rodent subfamilies of the Diatomyinae (Marković et al. in press) and the Melissiodontinae (Wessels et al. in press). Table 1 shows the rodent taxa present in the faunas from south-east Serbia; Paracricetodon occurs in six of the seven Serbian sites. In the late Eocene locality of Buštranje it is present with about $10 \%$ of the specimens and in the early Oligocene sites with 30 to $70 \%$ of the specimens.

European as well as Turkish small mammal faunas contain only a single species of Paracricetodon Schaub, 1925 (with a possible exception in Heimersheim, Germany; Bahlo 1975). The presence of three Paracricetodon species, co-occurring in two of our Serbian assemblages, leads us to review the species included in Paracricetodon.

Schaub (1925), in his classical work on Tertiary and extant hamster-like rodents, showed that the species Cricetodon spectabilis Schlosser, 1884 and Cricetodon cadurcensis Schlosser, 1884 are very similar in dental characteristics and in the shape of their mandibles, but differ essentially in these respects from Cricetodon proper and thus merit generic distinction. Consequently, he defined the genus Paracricetodon, designated Cricetodon spectabilis as the type, allocated the smaller species cadurcensis to his new genus and named a 
Table 1 The composition of the rodent faunas in south-east Serbia

\begin{tabular}{|c|c|c|c|c|c|c|c|c|c|c|}
\hline \multirow[t]{2}{*}{ Family } & \multirow[t]{2}{*}{ Subfamily } & \multirow[t]{2}{*}{ Genus and species } & \multicolumn{2}{|l|}{ Eocene } & \multicolumn{6}{|c|}{ Early Oligocene } \\
\hline & & & Zvonce & Buštranje & Strelac-1 & Strelac-2 & Strelac-3 & Valniš & Raljin & $\begin{array}{l}\text { Total } \\
\text { M1- M2 }\end{array}$ \\
\hline Diatomyidae & Diatomyinae & Inopinatia balkanica & & & 7 & 4 & 3 & 49 & 2 & 65 \\
\hline Dipodidae & primordial Zapodidae & Heosminthus borrae & & & & $\mathrm{X}$ & 22 & 20 & 1 & 43 \\
\hline \multirow[t]{15}{*}{ Muridae } & Pseudocricetodontinae & $\begin{array}{l}\text { Heterocricetodon } \\
\text { nov. sp. A }\end{array}$ & & & 14 & 5 & 6 & 49 & 4 & 78 \\
\hline & & $\begin{array}{r}\text { Pseudocricetodon } \\
\text { nov. sp. (small) }\end{array}$ & & 29 & & & 14 & & & 43 \\
\hline & & $\begin{array}{l}\text { Pseudocricetodon } \\
\text { montalbanensis }\end{array}$ & & & 4 & & 23 & 28 & 8 & 63 \\
\hline & Paracricetodontinae & Paracricetodon dehmi & & & 3 & & $\mathrm{X}$ & 10 & & 13 \\
\hline & & $\begin{array}{l}\text { Paracricetodon gracilis } \\
\text { nov. sp. }\end{array}$ & & & & & 2 & 11 & $?$ & 13 \\
\hline & & $\begin{array}{l}\text { Paracricetodon } \\
\quad \text { stojanovici nov. sp. }\end{array}$ & & 75 & 45 & 26 & 30 & 127 & 9 & 312 \\
\hline & Pappacricetodontinae & Witenia sp. & & & 5 & & $\mathrm{X}$ & 2 & & 7 \\
\hline & & nov. gen. 3 nov. sp. A & & 601 & & & & & & 601 \\
\hline & & Witenia nov. sp. A & & 21 & & & & & & 21 \\
\hline & Melissiodontinae & cf. Edirnella sp. 2 & & & 6 & 1 & & & & 7 \\
\hline & & Mogilia lautus & & & $\mathrm{X}$ & & & 34 & 1 & 35 \\
\hline & & Mogilia miloshi & 28 & 30 & & & & & & 58 \\
\hline & & cf. Edirnella sp. 1 & & 4 & & 1 & & & & 5 \\
\hline & & cf. Edirnella sp. indet. & $\mathrm{X}$ & & & & & & & 1 \\
\hline & ?Spalacinae & nov. gen.1 sp. A & 3 & & & & & & & 3 \\
\hline \multicolumn{3}{|c|}{ Total number of upper and lower M1 and M2 in each locality } & 31 & 760 & 84 & 37 & 100 & 330 & 25 & 1368 \\
\hline
\end{tabular}

third species on the basis of a single mandible of intermediate size, Paracricetodon confluens.

Unfortunately, the type specimens of all these three species originate from the karst-fissure fills of the Quercy (France) that were mined at the time, ground up and used as a phosphate fertiliser. The locality data with these specimens in old collections from the Quercy refer to the villages where the mills were located (i.e. Caylux, Moulliac) and give no information on the sites where the fossils came from.

Renewed collecting in the Quercy since 1963, originally by M. Freudenthal and P. Y. Sondaar (at the time Utrecht University and assisted in the field by the first author when he was a junior student) and somewhat later by L. Thaler and collaborators (Université des Sciences et Techniques du Languedoc, Montpellier), has shown that these karst fissures contain faunas that range in age from MP16 to MP28 (Remy et al. 1987). The oldest record of Paracricetodon in the Quercy comes from Lebratières 14, an assemblage that has been correlated with MP24 by Remy et al. (1987).

Paracricetodon material from the Quercy that has been studied in detail by Vianey-Liaud et al. (1995) comes from the MP 25 localities Garouillas and Rigal Jouet-1. They demonstrate that the only specimen that is still available of the type material of Paracricetodon cadurcensis is within the range of variation of the Paracricetodon specimens of these two MP 25 localities and provide an emended diagnosis of $P$. cadurcensis. In the meantime, it remains unknown to which Quercy fauna $P$. spectabilis and $P$. confluens belong.

In spite of extensive collecting in stratified as well as in karst deposits of Oligocene age since Schaub's days, Paracricetodon has remained a rare animal in central and western European assemblages. Samples that are large enough to allow the study of the intraspecific variation are known from the early Oligocene of Heimersheim (MP24; Bahlo 1975), Bernloch (MP24?; Hrubesch 1957), St Martin de Castillon (MP24; Hugueney and Adrover 1989-1990), Turkish Thrace ( MP24-25; Ünay-Bayraktar 1989), the Eocene/Oligocene boundary interval of the Lesser Caucasus (de Bruijn et al. 2003) and in south-east Serbia (this paper). The type species Paracricetodon spectabilis from the Quercy is, because of its larger size, a probably late member of this genus and from the periphery of its geographical range.

Mein and Freudenthal (1971), noting the unique dental characters of Paracricetodon, defined the monogeneric subfamily Paracricetodontinae in their classification of the Tertiary Cricetidae of Europe. Since then the content of this subfamily in terms of genera and its phylogenetical position within the Muridae has been disputed, so our usage needs explaining. 
Ünay-Bayraktar (1989) defined the genus Trakymys and included that in the Paracricetodontinae. In the same publication, she suggested that the Paracricetodontinae and the Melissiodontinae Schaub, 1925 (with the genera Melissiodon Schaub, 1920 and Edirnella Ünay-Bayraktar, 1989) are closely related and therefore are members of the same family. Freudenthal et al. (1992) did not agree with this arrangement, maintained the Melissiodontidae as a monogeneric family and transferred the genus Edirnella to the Paracricetodontinae. McKenna and Bell (1997) classified all the European Oligocene cricetids, except Melissiodon, as well as a number of North American genera in the Paracricetodontinae. They also followed Freudenthal et al. (1992) by including Edirnella in the Paracricetodontinae. Finally Kalthoff (2006) discussed the classification of the Eurasian Oligocene Muridae on the basis of the microstructure of the enamel of the lower incisors. The incisor enamel of Melissiodon (her type 1) appeared to be the most primitive known in murids and very different from the derived four-layered (type 8) that characterises the paracricetodontines Paracricetodon and Trakymys (Martin 1997; Kalthoff 2000). Unfortunately the isolated incisor studied by Kalthoff, that was supposed to belong to Edirnella, appeared to be a misidentified Trakymys tooth (Wessels et al. in press).

Our usage of the subfamily Paracricetodontinae is restricted to bunodont cricetids in which the lingual sinus of the M1 and M2 is directed posteriorly and the microstructure of the lower incisor shows four layers, and includes the genera Paracricetodon Schaub, 1925 and Trakymys Ünay-Bayraktar, 1989. The melissiodontines (including Melissiodon and Edirnella) from the late Eocene - early Oligocene rodent assemblages from Serbia are much more diverse than hitherto assumed and represent a clade that is not closely related to the Paracricetodontinae (Wessels et al. in press).

The eight formally named Paracricetodon species are as follows: P. spectabilis (Schlosser, 1884), P. cadurcensis (Schlosser, 1884) and P. confluens Schaub, 1925 from the Quercy (France), P. dehmi Hrubesch, 1957 and P. walgeri Bahlo, 1975 from Germany, P. kodjayarmensis ÜnayBayraktar, 1989 and P. kavakderensis Ünay-Bayraktar, 1989 from Turkish Thrace and $P$. wentgesi de Bruijn et al., 2003 from the lesser Caucasus (Turkey).

Figures 1, 2 and 3 clearly show that there are two size groups of Paracricetodon species: the small species are known from the Balkan and the lesser Caucasus region only; with the possible exception of the single $\mathrm{m} 2$ from Heimersheim in Germany. Figures 2 and 3 give the mean values of the length as well as the observed ranges of the lower respectively upper cheek teeth of the type material and of material of all known species of Paracricetodon.

The type material of Paracricetodon spectabilis, $P$. cadurcensis and P. confluens from the Quercy is very limited, so the intraspecific variation in size and morphology is not known (Figs. 2 and 3).The first well-documented species of Paracricetodon found is P. dehmi from Bernloch (Hrubesch 1957). From the description of that material we know that the variation in size as well as in morphology within a single association is large. The length-width scatters of Hrubesch have been digitised and shown here in Fig. 1. Hrubesch (1957) states that the teeth from Bernloch, although on average smaller than the three species known at the time, may show dental details that were, until then, used to distinguish these species.

Vianey-Liaud et al. (1995) in their study of the Paracricetodon material from Garouillas and Rigal-Jouet-1 confirmed this conclusion and observed that, although the morphological variation within single assemblages is great, the dental morphology remains essentially unchanged in different species; Hugueney and Adrover (1989-1990) came to a similar conclusion. The consequence of these observations is that the species Paracricetodon spectabilis, P. confluens and $P$. cadurcensis, which are each based on one or very few specimens, can be recognised by size only. Since the lengths of the molar of the type and the only specimen of $P$. confluens are within the expected, but insufficiently known, ranges of the molars of $P$. spectabilis and $P$. cadurcensis, we tentatively consider the name Paracricetodon confluens a nomen dubium (Fig. 2). Paracricetodon molars that match the size of the type specimen of $P$. cadurcensis are described by Vianey-Liaud et al. (1995), so this species is now adequately known on the basis of the material from the localities Garouillas and RigalJouet-1.P. cadurcensis is larger than P. dehmi but the size ranges show considerable overlap. Specimens that fit the $P$. cadurcensis size range are known from Sineu (Balearic Islands, Spain) and Terrenoire (France, Hugueney and Adrover, 1989-1990).

Figures 2 and 3 clearly show that Paracricetodon spectabilis, the type species of Paracricetodon, is not only the largest of all the Paracricetodon species, but also has the longest M3 relative to the M2, while $P$. wentgesi is the smallest and has, like $P$. gracilis, a short M3 relative to the M2. The relative dimensions of the upper and lower cheek teeth are stable throughout all the species of the genus otherwise. The length and dental morphology of the cheek teeth of P. dehmi, P. kodjayarmensis and P. kavakderensis overlap almost completely. In spite of the minor differences observed by Ünay-Bayraktar (1989), the species from Turkey are therefore tentatively considered to be junior synonyms of $P$. dehmi.

The assemblage from Belgarite 4A (Quercy) in the collection of the Faculty of Earth Sciences of Utrecht University (Fig. 9) fits the type material of Paracricetodon dehmi and is considered to represent that species. The lengths of the cheek teeth of $P$. dehmi s.l. show some overlap with those of the larger $P$. cadurcensis and the smaller $P$. walgeri, but the mean values of their cheek teeth differ sufficiently to maintain P. cadurcensis, P. dehmi and P. walgeri (Figs. 2 and 3). This conclusion is further supported by the total range of the size of these three species, which far exceeds the theoretically 

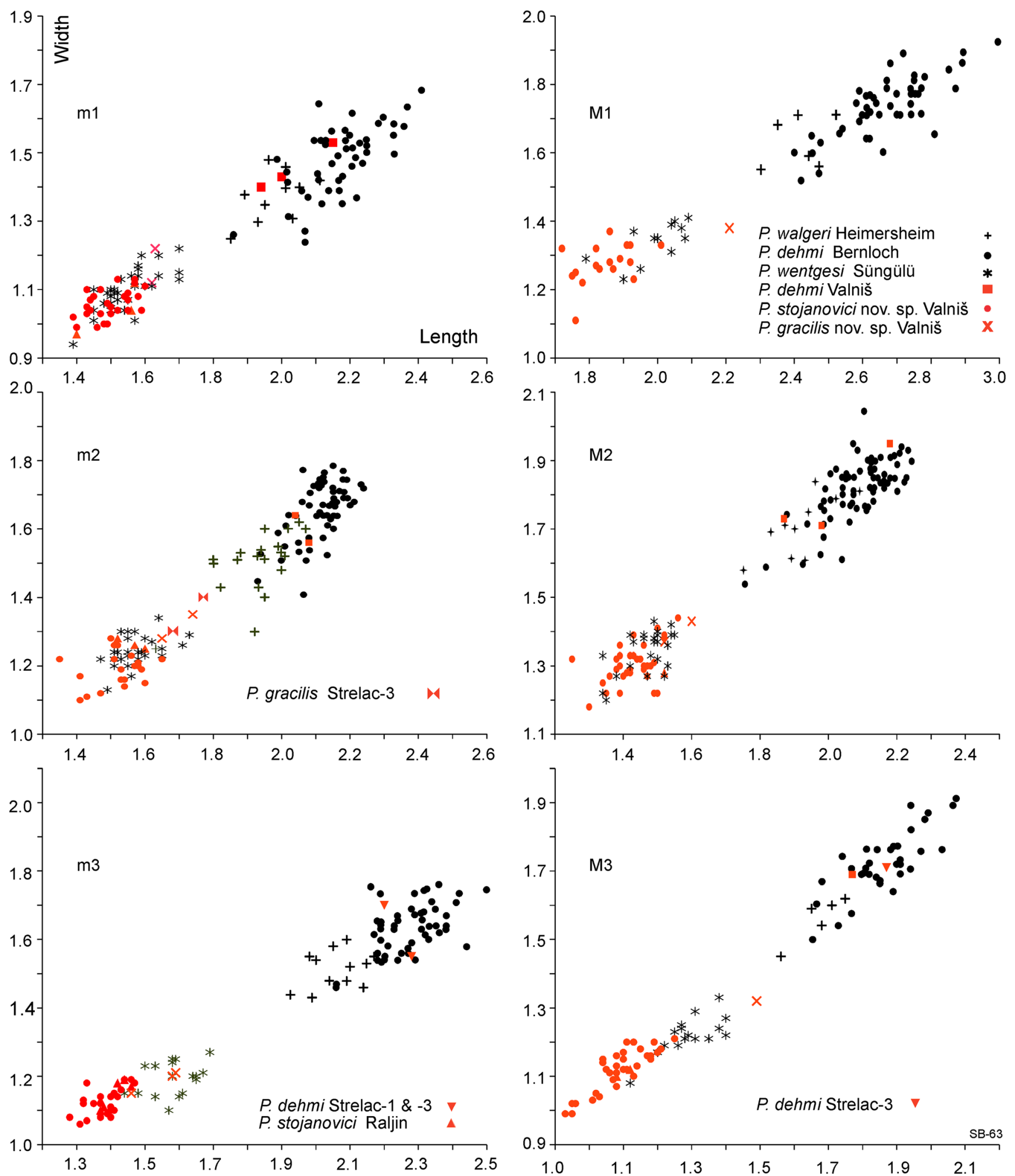

Fig. 1 Length-width scatter diagrams of the molars of Paracricetodon from south-east Serbia (in red) and from some selected species from other locations (in black)

expected range within one species. In spite of the reduction of the number of Paracricetodon species the overlap in size and morphology between them makes the identification of small samples to the species level difficult if not impossible.
The isolated Paracricetodon teeth from the Serbian Pčinja and Babušnica-Koritnica basins represent three species. One of these is small and is common in the Eocene site Buštranje as well as in all five early Oligocene localities in the Strelac 
Fig. 2 The length of the lower molars in Paracricetodon species from different localities. Shown are the average length and the range of the $\mathrm{m} 1, \mathrm{~m} 2$ and $\mathrm{m} 3$. The numbers between brackets behind the location names represent the numbers of $\mathrm{m} 1, \mathrm{~m} 2$ and $\mathrm{m} 3$ on which the averages and ranges are based

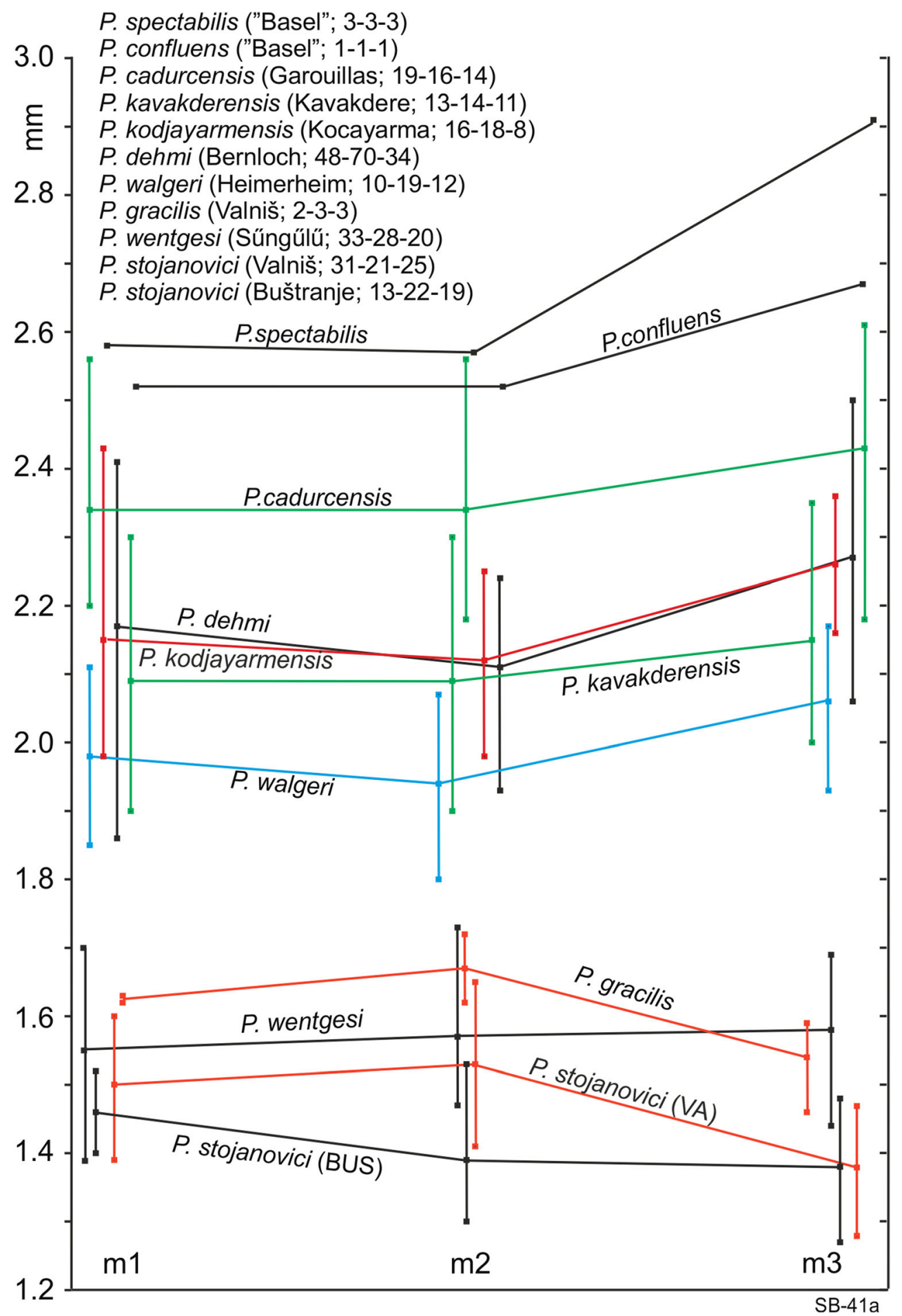

area. The second species is represented by a few specimens from the two larger Oligocene assemblages: Valniš and Strelac-1 and has been identified as Paracricetodon dehmi Hrubesch, 1957. The third species, also rare, is of medium size; it is present in Valniš and Strelac-3. A single aberrant $\mathrm{m} 3$ from Strelac-1 has been tentatively allocated to $P$. dehmi, however, it may document Trakymys. In two localities, Strelac3 and Valniš all three Paracricetodon species occur together.
As far as we know, western and central European faunas contain only a single species of Paracricetodon. A possible exception is Heimersheim (Germany) where next to $P$. walgeri a smaller species is perhaps documented by a small $\mathrm{m} 2$ in the scatter diagram (Bahlo 1975: fig. 16). It has a length and width of $1.63 \mathrm{~mm}$ and $1.25 \mathrm{~mm}$ respectively and is included diagram of Fig. 1, where it is hidden in the point cloud of P. wentgesi. 
Fig. 3 The length of the upper molars in Paracricetodon species from different localities. Shown are the average length and the range of the $\mathrm{M} 1, \mathrm{M} 2$ and $\mathrm{M} 3$. The numbers between brackets behind the location names represent the numbers of M1, M2 and M3 on which the averages and ranges are based



\section{Material and methods}

The isolated cheek teeth of the Paracricetodontinae from south-eastern Serbia are housed in the Natural History Museum in Belgrade (Serbia). A representative set of casts is kept in the collection of the department of Earth Sciences of Utrecht University, the Netherlands.

The terminology used for the description of the cheek teeth is illustrated in Fig. 4. 
Fig. 4 Terminology used in the description of cheek teeth of Paracricetodon

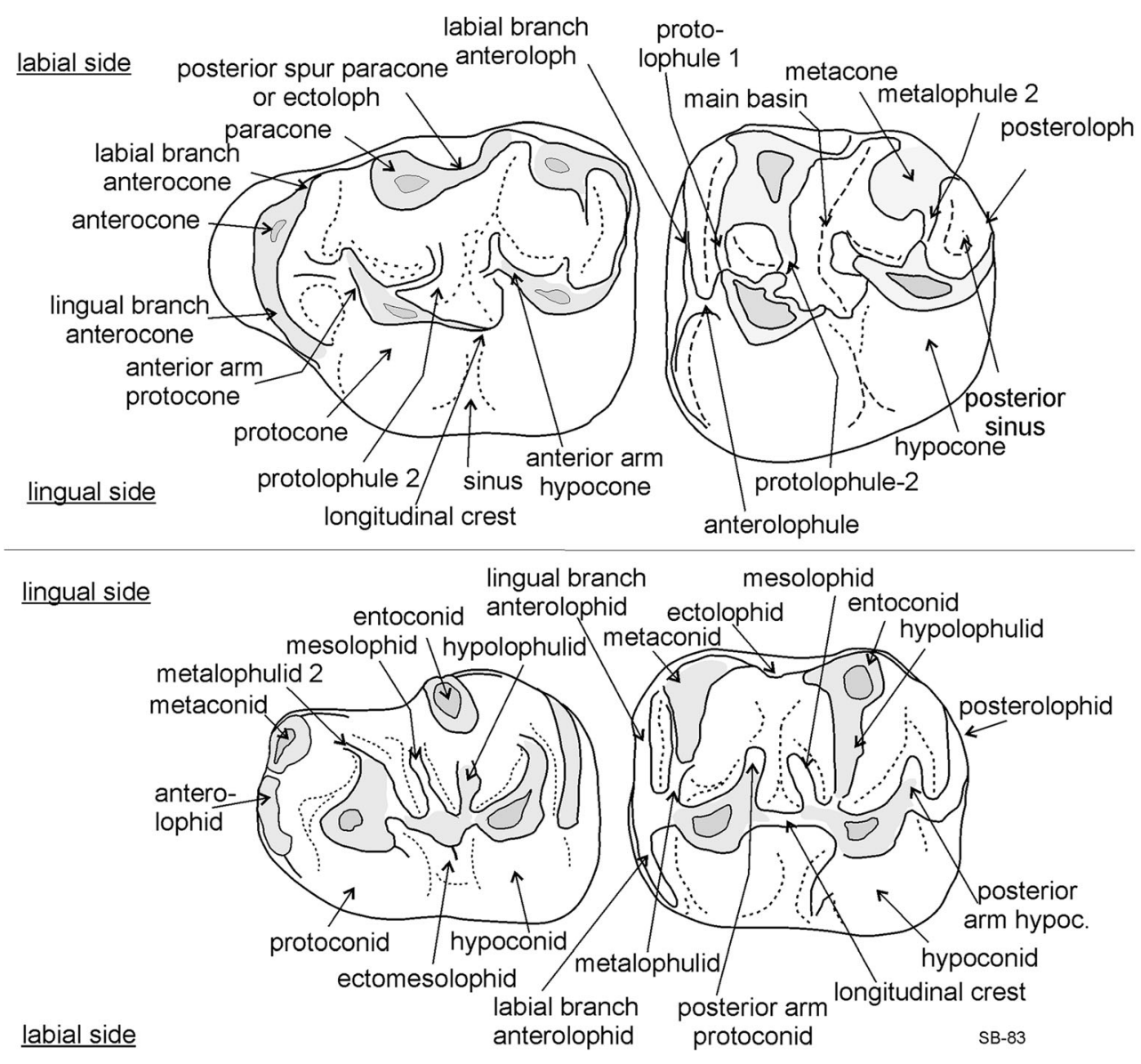

The measurements of the teeth have been taken with a Leitz Ortholux measuring microscope with mechanical stage and measuring clocks. The measurements used in the Figs. 2 and 3 have partly been taken from the literature, partly taken recently by colleagues or by our own, so there is a danger that the result is biased by the use of different measuring techniques and/or the usage of different measuring devices. This may in particular be the case for the values of the teeth from Bernloch, because the ranges of the length of the teeth given by Hrubesch (1957) for that sample are larger than expected and it is clear that the sophisticated measuring devices used nowadays were not available in 1957.

The pictures were made using a table-top SEM and a high-resolution SEM. All specimens are figured as left ones. If the original is from the right side, this is indicated by underlining its number on the figure. Lower case letters refer to the lower dentition, upper case letters refer to the upper dentition. Abbreviations for measurements and descriptions are as follows: dext-dextral, L-length, N-number of specimens, R-range of measurements, sin-sinistral and $\mathrm{W}$-width.
The abbreviations used for of the localities are as follows: Buštranje (BUS), Strelac-1 (STR-1), Strelac-2 (STR-2), Strelac-3 (STR-3), Valniš (VA) and Raljin (RA).The codes of the localities that yielded this material are: 031 for Buštranje, 024 for Strelac-1, 025 for Strelac-2, 026 for Strelac-3, 027 for Valniš and 028 for Raljin.

Abbreviations and terminology used in the description of the microstructure of enamel are as follows: HSB-Hunter Schreger band, IPM-inter prismatic matrix, PE-portio externa and PI-portio interna.

Used for comparison are casts of the specimens of P. spectabilis (Schlosser, 1884) and P. cadurcensis (Schlosser, 1884) that are figured in Schaub (1925), a cast of the type of $P$. confluens Schaub, 1925 and casts of P. dehmi Hrubesch, 1957, P. kavakderensis ÜnayBayraktar, 1989, P. kodjayarmensis Ünay-Bayraktar, 1989, P. wentgesi de Bruijn et al., 2003, Trakymys saratji Ünay-Bayraktar, 1989 as well as a sample of isolated Paracricetodon dehmi teeth from the Quercy collection made by Freudenthal and Sondaar in 19651967 labelled Belgarite 4A (all stored in the collection 

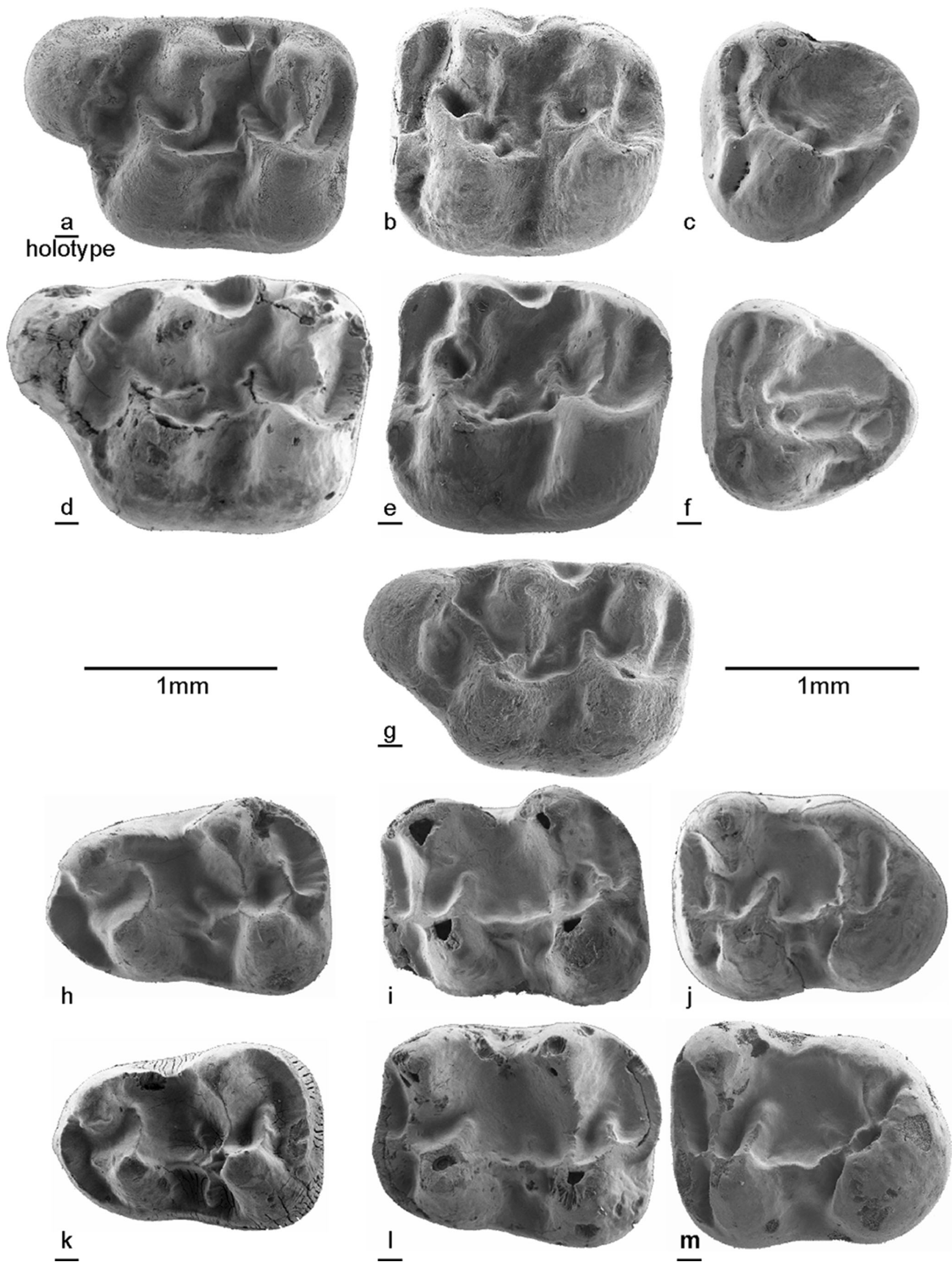
Fig. 5 Paracricetodon stojanovici nov. sp. from the type locality Buštranje. a M1 dext BUS-668 (holotype). b M2 sin BUS-682. c M3 sin BUS-704. d M1 dext BUS-671. e M2 dext BUS-694. f M3 dext BUS717. g M1 dext BUS-666. h m1 sin BUS-722. i m $2 \sin$ BUS-741. j m 3 sin BUS-762. $\mathbf{k} \mathrm{m} 1$ dext BUS-732. $\mathbf{l} \mathrm{m} 2$ dext BUS-754. $\mathbf{m} \mathrm{m} 3$ dext BUS-775

of Utrecht University, Department of Earth Sciences). Unfortunately the locality names used by the Dutch team for the Quercy fissures that yielded this material have not been harmonised with those used by French teams. This means that their biostratigraphical position within the Quercy sequence worked out by the French teams is not exactly known.

\section{Taxonomy}

Family Muridae Illiger, 1811

Subfamily Paracricetodontinae Mein and Freudenthal, 1971

Genera included: Paracricetodon Schaub,1925 and Trakymys Ünay-Bayraktar, 1989

\section{Genus Paracricetodon Schaub, 1925}

Type species: Cricetodon spectabilis Schlosser, 1884 Other species recognised: $P$. cadurcensis (Schlosser, 1884), P. dehmi Hrubesch, 1957 (= P. kavakderensis Ünay-Bayraktar, 1989; = P. kodjayarmensis Ünay-Bayraktar, 1989), P. walgeri Bahlo, 1975, P. wentgesi de Bruijn et al., 2003, P. stojanovici nov. sp. and $P$. gracilis nov. sp. Paracricetodon confluens Schaub, 1925 is considered to be a "nomen dubium" because it is based on a single mandible with $\mathrm{m} 1-\mathrm{m} 3$ that is intermediate in size between those of $P$. spectabilis and $P$. cadurcensis and lacks species-characteristic dental features.

Paracricetodon stojanovici nov. sp.

(Fig. 5, 7a-i, 8a-j,10)

Derivatio nominis: The species is named after Jovan Stojanović, in recognition of the way he cared for us during our stays in Babušnica.

Type locality: Buštranje.

Holotype: an isolated M1 dext.; VA-668 (Fig. 5a).

Occurrences: Valniš, Strelac-1, Strelac-2, Strelac-3, Raljin.

Material and measurements: see Table 2 (Buštranje),

Table 3 (Valniš), Table 4 (Strelac-1), Table 5 (Strelac-2) and

Table 6 (Strelac-3). Paracricetodon stojanovici nov. sp. is represented in the Raljin collection by a fragment of a mandible with $\mathrm{m} 1-\mathrm{m} 3$ and part of the lower incisor. These teeth could not be measured without destroying the specimen. Figures 5, 6, 7a-i, 8a-j and 10 .
Diagnosis: Paracricetodon stojanovici nov. sp. is small (Fig. 1). The M1, M2, M3, $\mathrm{m} 1$ and $\mathrm{m} 2$ are on average of the size of Paracricetodon wentgesi but the M3 and $\mathrm{m} 3$ fall below or in the lower range of that species. The $\mathrm{m} 3$ is on average somewhat shorter than the m1 (Fig. 2).

The M1 has a crescent-shaped anterocone that is almost as high as the protocone and paracone. The M2 has a protolophule 1 and a, weaker, protolophule 2 . The sinus of the sub-triangular M3 is either very small or absent. The anteroconid of the $\mathrm{m} 1$ is developed as a cingulum (anterolophid) that descends from the tip of the metaconid to the basis of the protoconid. The metalophulid 1 is absent and the metalophulid 2 is the posterior arm of the protoconid. The posterior arm of the hypoconid is more prominent than the metalophulid 2.

Differential diagnosis: Paracricetodon stojanovici falls in the size group of the small Paracricetodon species $P$. wentgesi and $P$. gracilis. All other species are considerably larger (Fig. 2). Paracricetodon stojanovici is very similar to $P$. wentgesi from Süngülü (late Eocene, Lesser Caucasus, Turkey). However, the M1, M2, m1 and $\mathrm{m} 2$ of $P$. stojanovici are on average somewhat smaller and the M3 and $\mathrm{m} 3$ are much smaller (Fig. 1) and have a more simple morphology than those of $P$. wentgesi. There are minor differences in the frequency distribution of the dental characters of the M1, M2, $\mathrm{m} 1$ and $\mathrm{m} 2$ between these species, but these are gradual and within the intraspecific variation of the two species. The main difference is that the most elaborate M3 of $P$. stojanovici has a simpler dental pattern than the most reduced M3 of $P$. wentgesi. A similar difference in the degree of reduction occurs in the $\mathrm{m} 3$ of these two species: the posterior part of this tooth is much narrower, the entoconid is lower and the mesolophid is absent in the specimens of $P$. stojanovici.

Description of the material from the type locality Buštranje

M1: The shape of the occlusal surface as well as the dental pattern show considerable variation. The well-developed

Table 2 Measurements of Paracricetodon stojanovici nov. sp. from Buštranje

\begin{tabular}{llllllll}
\hline & \multicolumn{2}{l}{ Length $(\mathrm{mm})$} & & & \multicolumn{2}{l}{ Width $(\mathrm{mm})$} \\
\cline { 2 - 3 } Buštranje & Range & Mean & $\mathbf{N}$ & & Mean & Range & N \\
\hline M1 & $1.68-1.90$ & 1.76 & 7 & 1.18 & $1.09-1.29$ & 16 \\
M2 & $1.25-1.47$ & 1.36 & 20 & 1.23 & $1.17-1.30$ & 19 \\
M3 & $1.05-1.28$ & 1.14 & 18 & 1.12 & $1.06-1.21$ & 19 \\
m1 & $1.40-1.52$ & 1.46 & 13 & 1.01 & $0.94-1.07$ & 17 \\
m2 & $1.30-1.53$ & 1.39 & 22 & 1.11 & $1.04-1.19$ & 22 \\
m3 & $1.27-1.48$ & 1.38 & 19 & 1.07 & $0.99-1.15$ & 19 \\
\hline
\end{tabular}


Table 3 Measurements of Paracricetodon stojanovici nov. sp. from Valniš

\begin{tabular}{llllllll}
\hline & \multicolumn{2}{l}{ Length $(\mathrm{mm})$} & & & \multicolumn{2}{l}{ Width $(\mathrm{mm})$} & \\
\cline { 2 - 3 } \cline { 7 - 8 } Valniš & Range & Mean & $\mathbf{N}$ & & Mean & Range & N \\
\hline M1 & $1.72-2.01$ & 1.86 & 20 & 1.27 & $1.11-1.37$ & 33 \\
M2 & $1.25-1.56$ & 1.42 & 37 & 1.31 & $1.18-1.44$ & 36 \\
M3 & $0.93-1.25$ & 1.09 & 38 & 1.12 & $0.99-1.21$ & 37 \\
m1 & $1.39-1.60$ & 1.50 & 34 & 1.06 & $0.99-1.13$ & 34 \\
m2 & $1.41-1.65$ & 1.53 & 24 & 1.20 & $1.10-1.28$ & 26 \\
m3 & $1.28-1.47$ & 1.39 & 30 & 1.13 & $1.06-1.19$ & 28 \\
\hline
\end{tabular}

crescent-shaped anterocone has a labial position. The lingual and labial branch of the anterocone reached the bases of the protocone and paracone respectively in most specimens. The anterior arm of the protocone is strong and connected to the labial side of the anterocone in some specimens. The narrow, low protolophule 2 is incomplete in some M1. The posterior spur of the paracone is burgee-shaped and is not or weakly connected to the metacone. The weak longitudinal crest is formed by the posterior arm of the protocone and defines the shape of the posteriorly directed sinus. In some specimens this ridge does not quite reach the base of the hypocone. The strong anterior arm of the hypocone may reach the base of the paracone, but in the majority this ridge ends free. The more or less transverse metalophule shows a wide range in development: in most M1 it is weak, but in others it is quite strong. The posteroloph curves from the tip of the hypocone to the base of the metacone delimiting a long narrow posterosinus.

M2: The long, straight anteroloph is divided into a long labial branch and a shorter lingual branch by the very short anterolophule. The high protocone and paracone are connected by a strong protolophule 1 (= anterior arm of the protocone) and a weaker protolophule 2 . These two lophs originate at the antero-labial corner of the

Table 4 Measurements of Paracricetodon stojanovici nov. sp. from Strelac-1

\begin{tabular}{llllllll}
\hline & \multicolumn{2}{l}{ Length $(\mathrm{mm})$} & & & \multicolumn{2}{l}{ Width $(\mathrm{mm})$} \\
\cline { 2 - 3 } \cline { 7 - 8 } Strelac-1 & Range & Mean & $\mathbf{N}$ & & Mean & Range & N \\
\hline M1 & $1.72-2.03$ & 1.90 & 9 & 1.26 & $1.16-1.34$ & 11 \\
M2 & $1.33-1.52$ & 1.44 & 15 & 1.33 & $1.22-1.43$ & 14 \\
M3 & $0.96-1.21$ & 1.12 & 13 & 1.14 & $1.02-1.23$ & 12 \\
m1 & $1.42-1.58$ & 1.50 & 8 & 1.07 & $0.94-1.14$ & 8 \\
m2 & $1.36-1.62$ & 1.52 & 11 & 1.16 & $1.06-1.27$ & 11 \\
m3 & $1.30-1.62$ & 1.44 & 8 & 1.18 & $1.00-1.26$ & 8 \\
\hline
\end{tabular}

Table 5 Measurements of Paracricetodon stojanovici nov. sp. from Strelac-2

\begin{tabular}{llllllll}
\hline & \multicolumn{2}{l}{ Length $(\mathrm{mm})$} & & & \multicolumn{2}{l}{ Width $(\mathrm{mm})$} \\
\cline { 2 - 3 } \cline { 7 - 8 } Strelac-2 & Range & Mean & $\mathbf{N}$ & & Mean & Range & N \\
\hline M1 & $1.72-2.08$ & 1.90 & 6 & 1.31 & $1.18-1.39$ & 7 \\
M2 & $1.31-1.58$ & 1.45 & 12 & 1.35 & $1.26-1.45$ & 11 \\
M3 & $1.06-1.18$ & 1.10 & 7 & 1.14 & $1.09-1.14$ & 7 \\
m1 & $1.43-1.57$ & 1.49 & 7 & 1.04 & $1.02-1.09$ & 7 \\
m2 & $1.40-1.51$ & 1.46 & 5 & 1.16 & $1.09-1.27$ & 5 \\
m3 & $1.35-1.43$ & 1.40 & 6 & 1.11 & $1.10-1.14$ & 5 \\
\hline
\end{tabular}

protocone. The high hypocone and metacone are connected by a strong metalophule 2 and a weaker metalophule 1 . These two lophs originate at the antero-labial corner of the hypocone.

The longitudinal ridge, which is formed by the posterior arm of the protocone, shows a considerable variation in height. The posterior spur of the paracone is burgeeshaped. The strong anterior arm of the hypocone reaches the base of the metacone in a few M2, in the others it ends freely in the main basin. The posteroloph connects the hypocone and metacone along the posterior limit of the occlusal surface.

M3: It shows a sub-triangular shape of the occlusal surface due to the near-absence of the hypocone. The anteroloph is divided into a long labial branch and a shorter lingual branch. The protocone, by far the largest cusp, is connected to the paracone by a straight, transverse protolophule. The pattern of the posterior part of the M3 shows considerable variation because of individual differences in the reduction of the hypocone, metacone and metalophule. In a few specimens, there is a remnant of the original longitudinal ridge preserved, but in the majority of the M3 the main basin shows some low cusps or ridges that are difficult to homologise. The hypocone and the metacone are incorporated into the posteroloph.

Table 6 Measurements of Paracricetodon stojanovici nov. sp. from Strelac-3

\begin{tabular}{llllllll}
\hline & \multicolumn{2}{l}{ Length $(\mathrm{mm})$} & & & \multicolumn{2}{l}{ Width $(\mathrm{mm})$} \\
\cline { 2 - 3 } Strelac-3 & Range & Mean & $\mathbf{N}$ & & Mean & Range & N \\
\hline M1 & - & 1.91 & 1 & 1.35 & $1.24-1.45$ & 4 \\
M2 & $1.34-1.51$ & 1.42 & 7 & 1.31 & $1.20-1.42$ & 7 \\
M3 & $1.02-1.13$ & 1.07 & 7 & 1.14 & $1.01-1.28$ & 7 \\
m1 & $1.40-1.65$ & 1.49 & 9 & 1.05 & $0.98-1.18$ & 9 \\
m2 & $1.37-1.60$ & 1.47 & 10 & 1.14 & $1.02-1.22$ & 9 \\
m3 & $1.32-1.35$ & 1.34 & 3 & 1.11 & $1.07-1.17$ & 4 \\
\hline
\end{tabular}



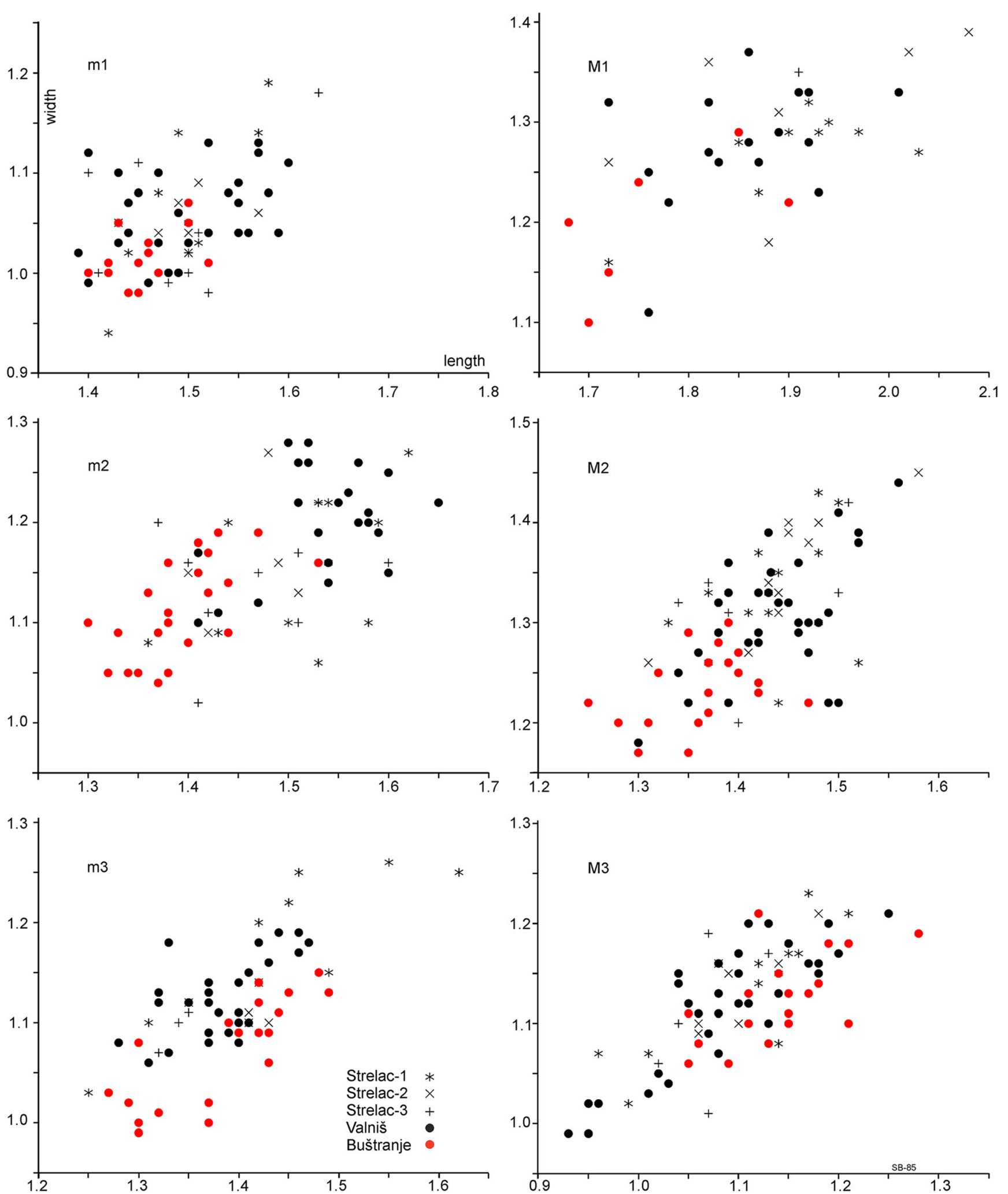

Fig. 6 Length-width scatter diagrams of the molars of Paracricetodon stojanovici from five localities in south-east Serbia

m1: It has a small anteroconid located on the anterolophid; it is much lower than the protoconid and the metaconid. In some $\mathrm{m} 1$ the anterolophid descends from the tip of the metaconid to the base of the protoconid. The high metaconid and entoconid are situated somewhat anteriorly of the protoconid and hypoconid. The metalophulid 1 is absent. The strong posterior arm of the protoconid reaches the base of the metaconid (forming a metalophulid 2) in most $\mathrm{m} 1$, in the others this ridge 

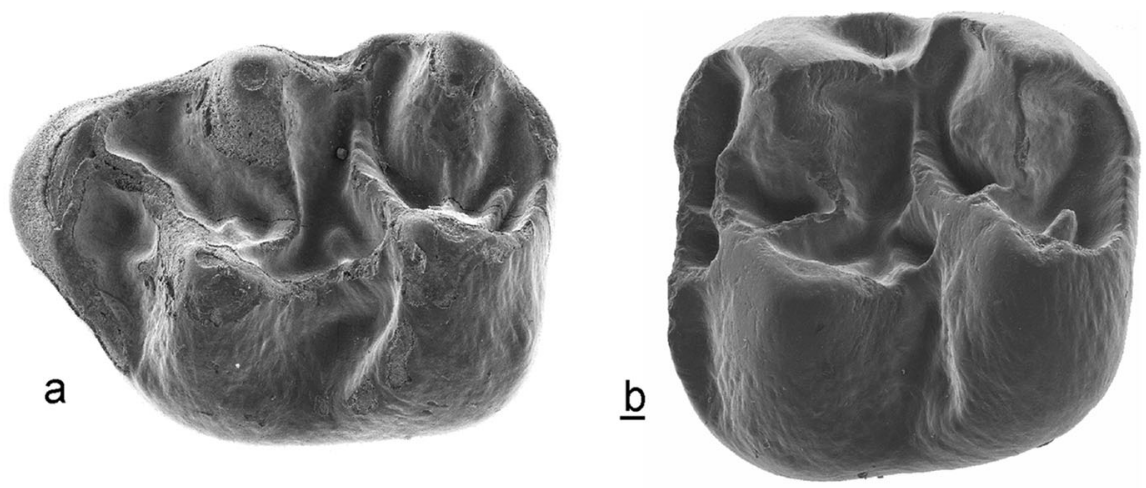

$\underline{c}$
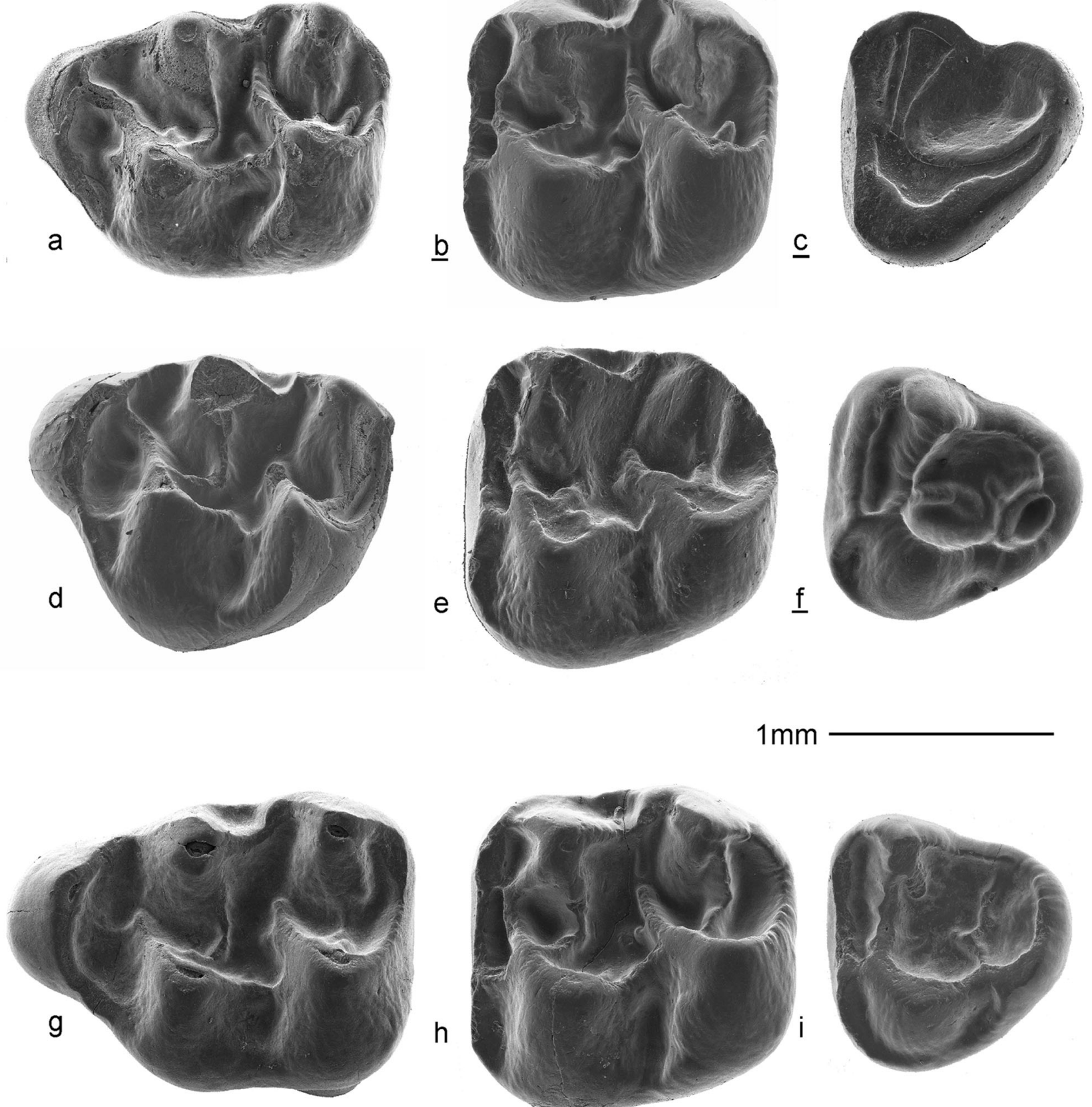

h
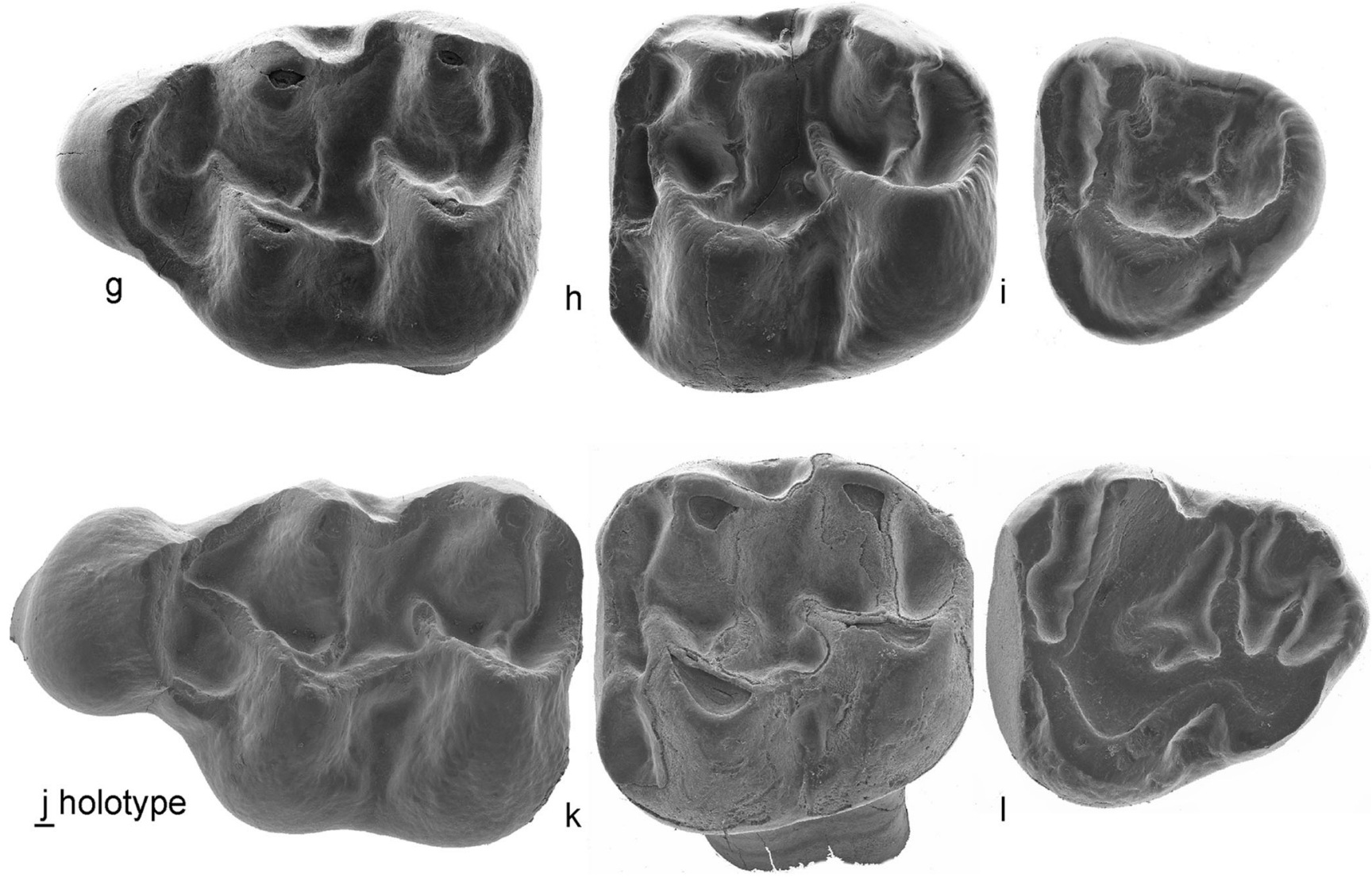
4 Fig. 7 Upper dentition of Paracricetodon stojanovici nov. sp. and P. gracilis nov. sp. from Valniš. Paracricetodon stojanovici nov. sp.: a M1 sin VA-630, b M2 dext VA-667, c M3 dext VA-724, d M1 sin VA652, e M2 VA-682, f M3 dext VA-723, g M1 sin VA-623, h M2 sin VA678, i M3 sin VA-714. Paracricetodon gracilis nov. sp.: j (holotype) M1 dext VA-831, k M2 sin VA-834, 1 M3 sin VA-840

ends free in the main basin. The metaconid and the entoconid are connected by a narrow ectolophid. The longitudinal ridge is low, but complete and may bear a weak mesolophid and ectomesolophid. The low hypolophulid is directed slightly forwards and inserts on the longitudinal ridge. The strong posterior arm of the hypoconid reaches the base of the entoconid in some specimens, but in others it ends free. The posterolophid is complete and lower than the posterior arm of the hypoconid.

m2: The curved labial branch of the anterolophid is shorter than the straight lingual branch. The high metaconid and entoconid are situated somewhat anteriorly of the protoconid and hypoconid. The short, weak metalophulid is almost transverse and inserts on the anterolophule in front of the protoconid. The protoconid and hypoconid are connected by the longitudinal crest and the metaconid and entoconid are connected by an ectolophid. The strong posterior arm of the protoconid reaches the metaconid in some specimens (forming a metalophulid 2), but in others it ends free. A weak mesolophid is present in some specimens. The hypolophulid is more or less transverse and inserts on the longitudinal ridge in front of the hypoconid or is connected to the anterior part of the hypoconid. The posterior arm of the protoconid and the hypoconid have about the same length, except in some $\mathrm{m} 2$ where the posterior arm of the hypoconid reaches the base of the entoconid, forming a hypolophulid 2. The posterolophid curves smoothly from the posterior side of the hypoconid to the entoconid.

m3: The short anterolophulid divides the anterolophid into a short curved labial branch and a longer straight lingual branch. The metaconid and entoconid are situated slightly anteriorly of the protoconid and hypoconid. The metalophulid 1 is approximately transverse and inserts on the anterolophulid or on the anterior part of the protoconid. The strong posterior arm of the protoconid ends freely in the majority of the $\mathrm{m} 3$, but reaches the base of the metaconid in some others. The mesolophid is absent. The short, transverse hypolophulid inserts on the longitudinal ridge in front of the hypoconid. The metaconid is connected to the weak entoconid by an ectolophid. The posterior arm of the hypoconid is absent. The posterolophid is connected to the entoconid.

\section{Remarks}

The Paracricetodon stojanovici nov. sp. molars from Valniš, Strelac-1, Strelac-2, Strelac-3 and Raljin do not differ in size; the Paracricetodon stojanovici nov. sp. molars from the type locality Buštranje (Eocene) tend to be slightly smaller than those of the Oligocene localities in the Strelac area (Fig. 6) except for the M3. The M3 of the Oligocene populations (black symbols in Fig. 6) have more smaller specimens suggesting a trend toward reduction in size. Morphologically the populations from Valniš, Strelac-1, -2, -3 and Raljin are within the range of variation of the collection from the type locality. The similarity in morphology and the somewhat larger size of the younger samples suggest an ancestor, descendant relationship, but the slight size difference does not warrant specific separation. The material of Paracricetodon stojanovici nov. sp. differs from $P$. wentgesi mainly by its smaller size (Figs. 1, 2 and 3 ) and the simpler dental pattern of the M3/m3. Otherwise the difference between these species is limited to differences in frequency of such morphological character states as the length of the anterior arm of the protocone in the M2 and the frequency of a forwards directed metalophulid 1 in the $\mathrm{m} 2$. The similarity of $P$. stojanovici nov. sp. and $P$. wentgesi suggests that these species are closely related, but there does not seem to be a direct ancestor - descendant relationship, because, while we see size increase through time in the Serbian material, $P$. stojanovici nov. sp. from the Oligocene is smaller and has more reduced $\mathrm{M} 3 / \mathrm{m} 3$ than $P$. wentgesi from the late Eocene of Turkey. Although our age control is poor there are good reasons to assume that the locality Süngülü is about coeval with Buštranje and older than the localities in the Strelac area.

Paracricetodon gracilis nov. sp.

(Fig. 7j-1; Fig. 8k-n)

Derivatio nominis: gracilis in Latin means slender. The M1 of this species is relatively long and narrow for a paracricetodontine.

Type locality: Valniš.

Holotype: One isolated M1dext. VA-831 (Fig. 7j).

Occurrences: Strelac-3.

Material and measurements: Valniš: Table 7 and Figs. 1, 6, $7 \mathrm{j}-1$ and $8 \mathrm{k}-\mathrm{n}$, Strelac-3: Two $\mathrm{m} 2$; L x W: 1.68-1.77 mm; $1.30-1.40 \mathrm{~mm}$.

Diagnosis: The M1, M2, M3, $\mathrm{m} 1$ and $\mathrm{m} 2$ are on average intermediate in size between those of the larger Paracricetodon walgeri and the smaller P. wentgesi and $P$. stojanovici. The length of the M2 overlaps the range of $P$. wentgesi and the length ranges of the $\mathrm{m} 1, \mathrm{~m} 2$ and $\mathrm{m} 3$ overlap with those of $P$. stojanovici and $P$. wentgesi. The narrow anterocone of the M1 is situated far forwards, which gives this tooth a, for Paracricetodon unusual, gracile appearance. The dental pattern of the M3 is not much reduced and shows a hypocone, metalophule and mesoloph. The $\mathrm{m} 3$ is on average shorter than the $\mathrm{m} 1$.

Differential diagnosis: Paracricetodon gracilis differs from all other Paracricetodon species by having an elongate gracile 


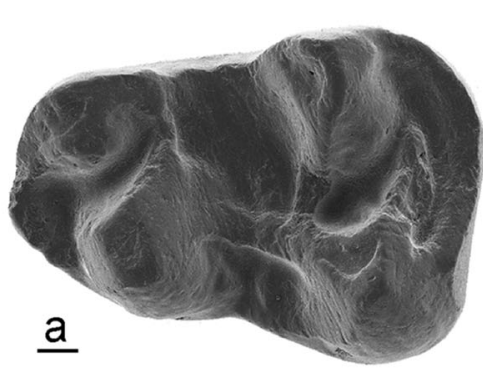

$\underline{b}$
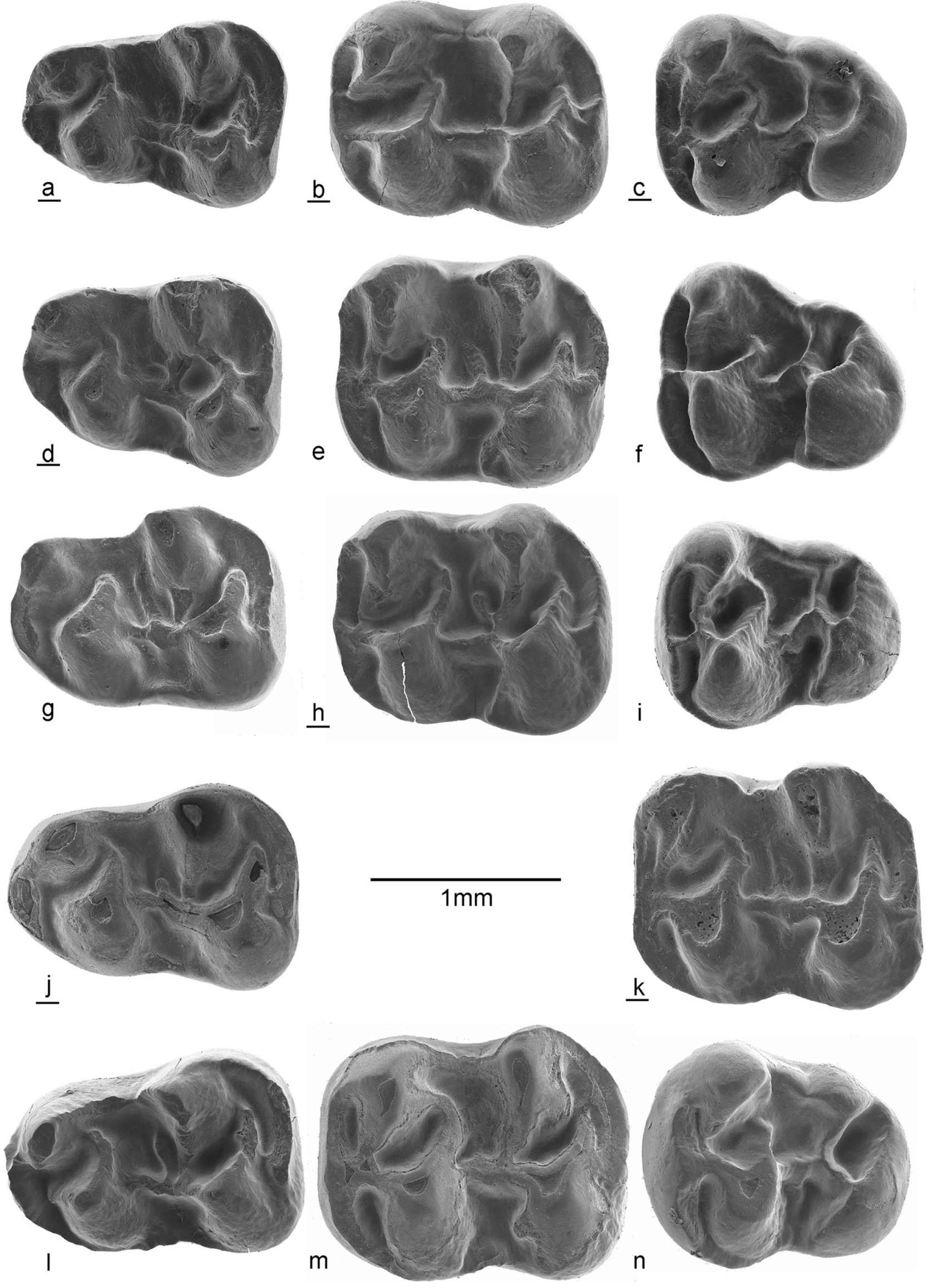
4 Fig. 8 Lower dentition of Paracricetodon stojanovici nov. sp. and $P$. gracilis nov. sp. from Valniš. Paracricetodon stojanovici nov.sp.: a m1 dext VA-761, b $\mathrm{m} 2$ dext VA-782, $\mathbf{c} \mathrm{m} 3$ dext VA-813, $\mathbf{d} \mathrm{m} 1$ dext VA-742, e $\mathrm{m} 2 \sin \mathrm{VA}-777, \mathbf{f} \mathrm{m} 3 \sin \mathrm{VA}-1016, \mathbf{g} \mathrm{m} 1 \sin \mathrm{VA}-740, \mathbf{h} \mathrm{m} 2$ dext VA784, i m3 sin VA-821, j m1 dext VAL-020; Paracricetodon gracilis nov.sp.: $\mathbf{k}$ m2 dext VA-846, $\mathbf{l}$ m1 sin VA-841, $\mathbf{m}$ m2 sin VA-845, $\mathbf{n}$ m3 $\sin$ VA-848

M1 and from all other species except $P$. stojanovici by having an $\mathrm{m} 3$ that is shorter than the $\mathrm{m} 2$. Although the morphology of the cheek teeth of $P$. gracilis is essentially similar to that of other species of Paracricetodon, the length/width ratio of its M1 in combination with a relatively short $\mathrm{m} 3$ are unique.

\section{Description of the type material from Valniš}

M1: The rather narrow anterocone is situated at about the same distance from the protocone and paracone as there is between the latter cusps and the metacone and hypocone. The four main cusps have about the same size and height. The anterocone, paracone and metacone are connected along the labial margin by an ectoloph. The anterior arm of the protocone reaches the postero-labial base of the anterocone. The somewhat shorter anterior arm of the hypocone does not reach the ectoloph. The lingual branch of the anterocone connects this cusp to the protocone. The shape of the sinus is determined by the posterior arm of the protocone. The short, weak protolophule and metalophule are slightly forwards directed and insert on the protocone and hypocone, respectively. The posteroloph descends from the hypocone and ascends labially to the metacone.

M2: The occlusal surface is sub-square. The low anteroloph occupies all of the anterior border of the M2 and continues as a cingulum to the postero-lingual side of the protocone and to the postero-labial side of the paracone. The four main cusps are large and the lophs are subordinate to the cusps. The parallel anterior arms of the protocone and hypocone are strong and end free.

Table 7 Measurements of Paracricetodon gracilis nov. sp. from Valniš

\begin{tabular}{llllllll}
\hline & \multicolumn{2}{l}{ Length $(\mathrm{mm})$} & & & \multicolumn{2}{l}{ Width $(\mathrm{mm})$} \\
\cline { 2 - 3 } \cline { 7 - 8 } Valniš & Range & Mean & $\mathbf{N}$ & & Mean & Range & N \\
\hline M1 & $2.20-2.21$ & 2.21 & 2 & 1.38 & $1.37-1.38$ & 2 \\
M2 & $1.52-1.60$ & 1.56 & 2 & 1.40 & $1.37-1.43$ & 2 \\
M3 & - & 1.49 & 1 & 1.32 & - & 1 \\
m1 & $1.62-1.63$ & 1.63 & 2 & 1.19 & $1.12-1.22$ & 3 \\
m2 & $1.62-1.72$ & 1.67 & 3 & 1.32 & $1.28-1.35$ & 2 \\
m3 & $1.46-1.59$ & 1.54 & 3 & 1.19 & $1.15-1.21$ & 3 \\
\hline
\end{tabular}

The short protolophule and metalophule are directed forwards and insert on the protocone and hypocone, respectively. The posterior spur of the paracone is strong and forms an ectoloph. The sinus is delimited by the posterior arm of the protocone. The posteroloph descends from the hypocone and ascends labially to the tip of the metacone.

M3: The dental pattern of the elongate M3 is not reduced. The narrow anteroloph is straight. The protocone is larger than the prominent hypocone. The protocone and hypocone are connected by the posterior arm of the protocone. The paracone is larger than the prominent metacone. The forwards directed protolophule and metalophule are both complete. The anterior arm of the hypocone forms a long straight mesoloph, which reaches the labial border of the occlusal surface.

m1: The anteroconid is developed as a ridge that is much lower than the protoconid and metaconid. This incipient anteroconid hardly adds to the length of the $\mathrm{m} 1$. The four main cusps are robust, but the longitudinal crest and ectolophid are weak. The posterior arm of the protoconid is connected to the base of the metaconid, but the posterior arm of the hypoconid ends free. The short transverse hypolophulid is weak. The posterolophid descends from the hypoconid and ascends lingually to the tip of the entoconid. The mesolophid is weak.

m2: The labial branch of the anterolophid is longer than the lingual branch. The metalophulid 1 and the hypolophulid are directed somewhat anteriorly and insert in front of the protoconid and hypoconid, respectively. The parallel posterior arms of the protoconid and hypoconid are about equally strong, but the former connects to the base of the metaconid, while the latter ends free. The metaconid and entoconid are connected by an ectolophid and the protoconid and hypoconid are connected by the longitudinal crest, which delimits the more or less symmetrical sinusid. The posterolopid descends from the hypoconid and ascends lingually to the tip of the entoconid.

m3: Recognition of the isolated $\mathrm{m} 3$ of Paracricetodon gracilis nov. sp. poses a problem, because that supposedly small tooth is only very slightly larger than the $\mathrm{m} 3$ of P. stojanovici. One of the three m3 (VA-848, Fig. 8n) that we tentatively allocate to $P$. gracilis is somewhat more robust than the other two and is therefore with confidence considered to belong to $P$. gracilis. Our description of the $\mathrm{m} 3$ is therefore based on this specimen. The labial branch of the anterolophid is much stronger than the lingual branch and continues as a well-delimited cingulum along the labial side of the protoconid. The cusps are robust and the short, low metalophulid and hypolophulid are directed forwards. The posterior arm of the protoconid ends free in the main basin. The posterior arm of the hypoconid is absent. The entolophid and ectolophid are low, but the strong posterolophid is connected to the well-delimited entoconid. 


\section{Remarks}

The type material of this species is unfortunately somewhat meagre, due to limited access to the locality. Reason for the lack of an adequate collection of $P$. gracilis is that we had to pay a considerable amount of money to the land owner of the Valniš site in order to obtain his permission for further collecting, which we refused. As a result there remains some uncertainty about the allocation of the lower cheek teeth to Paracricetodon gracilis. Our decision to regard $P$. gracilis as a separate species is based on the size as well as on the morphology of the upper cheek teeth. Moreover, the sole complete M1, the three M2 and the unique M3 are neatly intermediate in size between the teeth of the larger $P$. dehmi and $P$. walgeri and the smaller $P$. wentgesi and P. stojanovici (Fig. 1). The identification of the lower cheek teeth of $P$. gracilis is more problematic, because their size difference relative to $P$. gracilis and $P$. stojanovici is small. It can therefore not be excluded that the identification of the lower cheek teeth of $P$. gracilis is not correct, but concerns large specimens of $P$. stojanovici.

In our experience, the relative size of the cheek teeth within rodent genera is rather stable. This even so when details of the dental pattern change through time. If our allocation of the lower cheek teeth to $P$. stojanovici and $P$. gracilis is correct these two species from Serbia have $m 3$ that are shorter than the $\mathrm{m} 2$, while all other species of Paracricetodon have $\mathrm{m} 3$ that are longer than the $\mathrm{m} 2$ (Fig. 3).

\section{Paracricetodon dehmi Hrubesch, 1957}

(Fig. 9a, b, g, h, i)

\section{P. kavakderensis Ünay-Bayraktar, 1989 \\ P. kodjayarmensis Ünay-Bayraktar, 1989 \\ P. cf. kavakderensis (in Doukas and Theocharopoulos 1999)}

Type locality: Bernloch (Germany).

Occurrences: Kavakdere and Kocayarma (Turkish Thrace), Kyprinos (Greek Thrace), Belgarite 4A (Quercy, France), Valniš and Strelac-1 (south-east Serbia).

Material and measurements: Valniš: Table 8 and Figs. 1, 9a, b, g-i, Strelac-1: Table 9.

\section{Description of the specimens}

M1: The only M1 from south-east Serbia (Fig. 9a) is damaged anteriorly. The short anterior arms of the protocone and hypocone are parallel. The transverse protolophule and metalophule insert on the protocone and the hypocone, respectively. The sinus is directed posteriorly. The posterior spur of the paracone reaches the base of the metacone. The posteroloph is connected to the metacone.
M2: The occlusal surface of the three M2 from Valniš is somewhat narrower posteriorly than anteriorly. The weak anteroloph of two M2 is not divided by an anterolophule into a lingual and labial branch. The parallel, forwards directed anterior arms of the protocone and hypocone are rather short and end free. The short protolophule and metalophule bend slightly forwards and insert on the protocone and hypocone, respectively. The posteroloph is connected to the metacone.

M3: The only M3 available is unfortunately rather worn. The anteroloph of this sub-triangular tooth is weak. The protocone has a short free ending anterior arm. The protolophule connects the paracone to the protocone and there are remnants of the metalophule. The hypocone is very small and the sinus is shallow.

m1: The "anteroconid" is a low cingulum that hardly adds to the length of the $\mathrm{m} 1$ (Fig. 9g). An anterolophulid divides the weak anterolophid into a short lingual and a somewhat longer labial branch. A true metalophulid 1 is missing and the short metalophulid 2 is formed by the posterior arm of the protoconid. The longitudinal crest is low. Two of the three specimens show a small ectomesolophid as well as a double mesolophid, but these structures are absent in the third. The low ectolophid is formed by the posterior spur of the metaconid and the anterior spur of the entoconid. The posterior arm of the hypoconid is short and ends free. The posterolophid descends from the hypoconid and ascends lingually to the tip of the entoconid.

m2: Two of the three $\mathrm{m} 2$ are so badly worn that the details of the dental pattern are not visible. The third one (Fig. 9h) has robust cusps, but a weak anterolophid. The ectolophid and longitudinal crest are low. The metalophulid and hypolophulid are transverse and insert on the anterior side of the protoconid and hypoconid, respectively. The parallel posterior arms of the protoconid and hypoconid are short and end free. There is a trace of a mesolophid. The rather low posterolophid reaches to the tip of the entoconid.

m3: The two $\mathrm{m} 3$ in the size category of Paracricetodon dehmi are rather different. Number STR-1-288 (Fig. 9i) is elongate and narrow posteriorly like the ones from Bernloch (Hrubesch, 1957). The other (STR-1-289, not illustrated) is

Table 8 Measurements of Paracricetodon dehmi from Valniš

\begin{tabular}{llllllll}
\hline & \multicolumn{2}{l}{ Length $(\mathrm{mm})$} & & & \multicolumn{2}{l}{ Width $(\mathrm{mm})$} \\
\cline { 2 - 3 } Valniš & Range & Mean & $\mathbf{N}$ & & Mean & Range & N \\
\hline M2 & $1.87-2.18$ & 2.01 & 3 & 1.84 & $1.71-1.95$ & 3 \\
M3 & - & 1.77 & 1 & 1.69 & - & 1 \\
m1 & $1.94-2.15$ & 2.03 & 3 & 1.45 & $1.40-1.53$ & 3 \\
m2 & $2.04-2.08$ & 2.06 & 2 & & 1.60 & $1.56-1.64$ & 2 \\
\hline
\end{tabular}




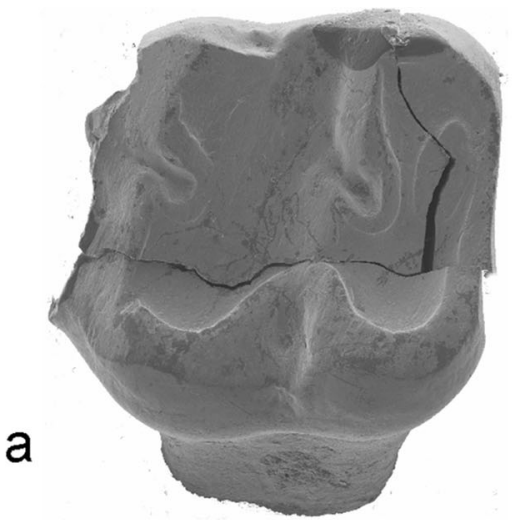

b

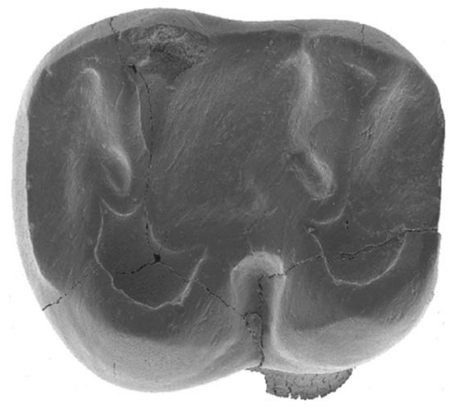

e

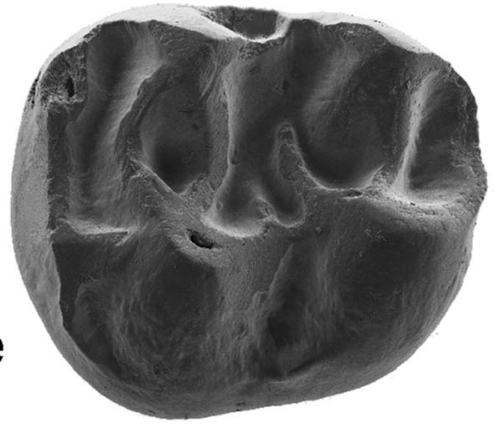

h

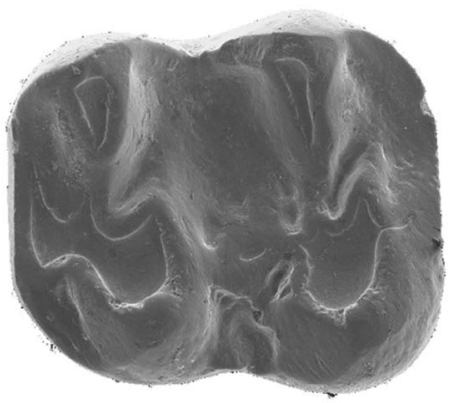

$\mathrm{k}$

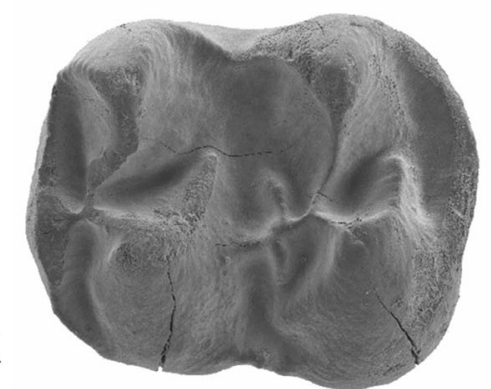

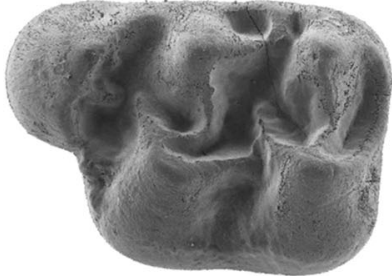

C

$1 \mathrm{~mm}$

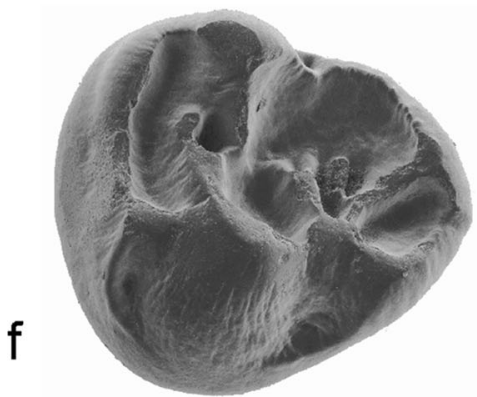

i
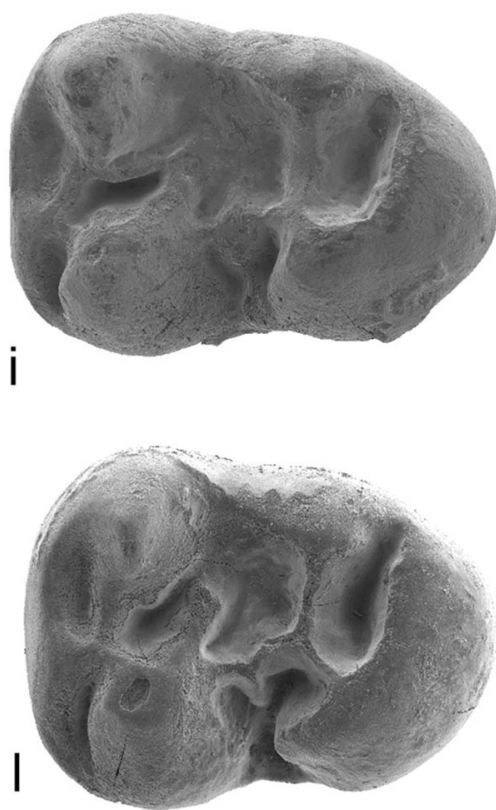

Fig. 9 Paracricetodon dehmi from Valniš, Strelac-3 (Serbia) and Belgarite (France). For comparison of size, a M1 of $P$. stojanovici nov. sp. (c BUS-682) has been added to the figure. Paracricetodon dehmi from Valniš and Strelac-3: a M1 sin STR-1-281, b M2 sin VA-856, g m1 dext

much wider posteriorly, lacks the strong posterior arm of the protoconid and shows traces of irregular ridges within the central basin. This specimen resembles Trakymys saratji Ünay-Bayraktar, 1989 much more than Paracricetodon dehmi. Our tentative allocation of this $\mathrm{m} 3$ to the latter species
VA-862, h m2 sin VA-866, i m3 sin STR1-288. Paracricetodon dehmi from Belgarite (Fr): d M1 sin BEL-401, e M2sin BEL-403, f M3 sin BEL-404, j m1 sin BEL-403, $\mathbf{k}$ m2 sin BEL-406, 1 m3 sin BEL-407

is induced by our reluctance to enter a taxon to the fauna list which is based on one, possibly aberrant, $\mathrm{m} 3$ only. The description is based on the slender specimen. The anterolophid is low and divided by the anterolophulid in a short labial and a longer lingual branch. The metalophulid and the hypolophulid 
Table 9 Measurements of Paracricetodon dehmi from Strelac-1

\begin{tabular}{llllllll}
\hline & \multicolumn{2}{l}{ Length $(\mathrm{mm})$} & & & \multicolumn{2}{l}{ Width $(\mathrm{mm})$} \\
STR-1 & Range & Mean & $\mathbf{N}$ & & Mean & Range & N \\
\hline M1 & - & - & - & 1.88 & - & 1 \\
$\mathrm{~m} 1$ & - & 2.03 & 1 & 1.45 & - & 1 \\
$\mathrm{~m} 2$ & - & 2.11 & 1 & & 1.66 & - & 1 \\
$\mathrm{~m} 3$ & $2.20-2.28$ & 2.24 & 2 & & 1.63 & $1.55-1.70$ & 2 \\
\hline
\end{tabular}

are directed slightly forwards and insert in front of the protoconid and hypoconid, respectively. The posterior arm of the protoconid ends free. The low ectolophid bears a distinct mesoconid. The posterior arm of the hypoconid is absent. The posterolophid connects the hypoconid to the entoconid.

\section{Remarks}

The teeth from Valniš and Strelac-1 allocated to Paracricetodon dehmi match the ones in the type series from Bernloch in every respect. A reconstructed dentition of
P. dehmi from Belgarite 4A is figured for comparison (Fig. $9 \mathrm{~d}-\mathrm{f}, \mathrm{j}-\mathrm{l})$, because the photographs of the type material given by Hrubesch (1957), antedating the invention of the scanning electron microscope, are not very clear.

\section{The lower incisors}

Matching isolated incisors with the cheek teeth is often difficult and a possible source of mistakes. This in particular so when the associations studied contain a diverse array of Muridae subfamilies as in the localities of the Strelac area and in Buštranje. Fortunately the Paracricetodontinae studied so far by Kalthoff $(2000,2006)$ are known to have a very derived four-layered schmelzmuster in the lower incisor and are therefore potentially readily recognisable. Testing transverse sections of the various incisor types from Buštranje showed that the, for Paracricetodon characteristic specialised type 8 enamel (Kalthoff 2000), occurs in lower incisors from Buštranje. The outer enamel surface of these specimens shows seven to eight longitudinal, distally somewhat tangential ribs (Fig. 10b). Similar ribs are illustrated by Hugueney and
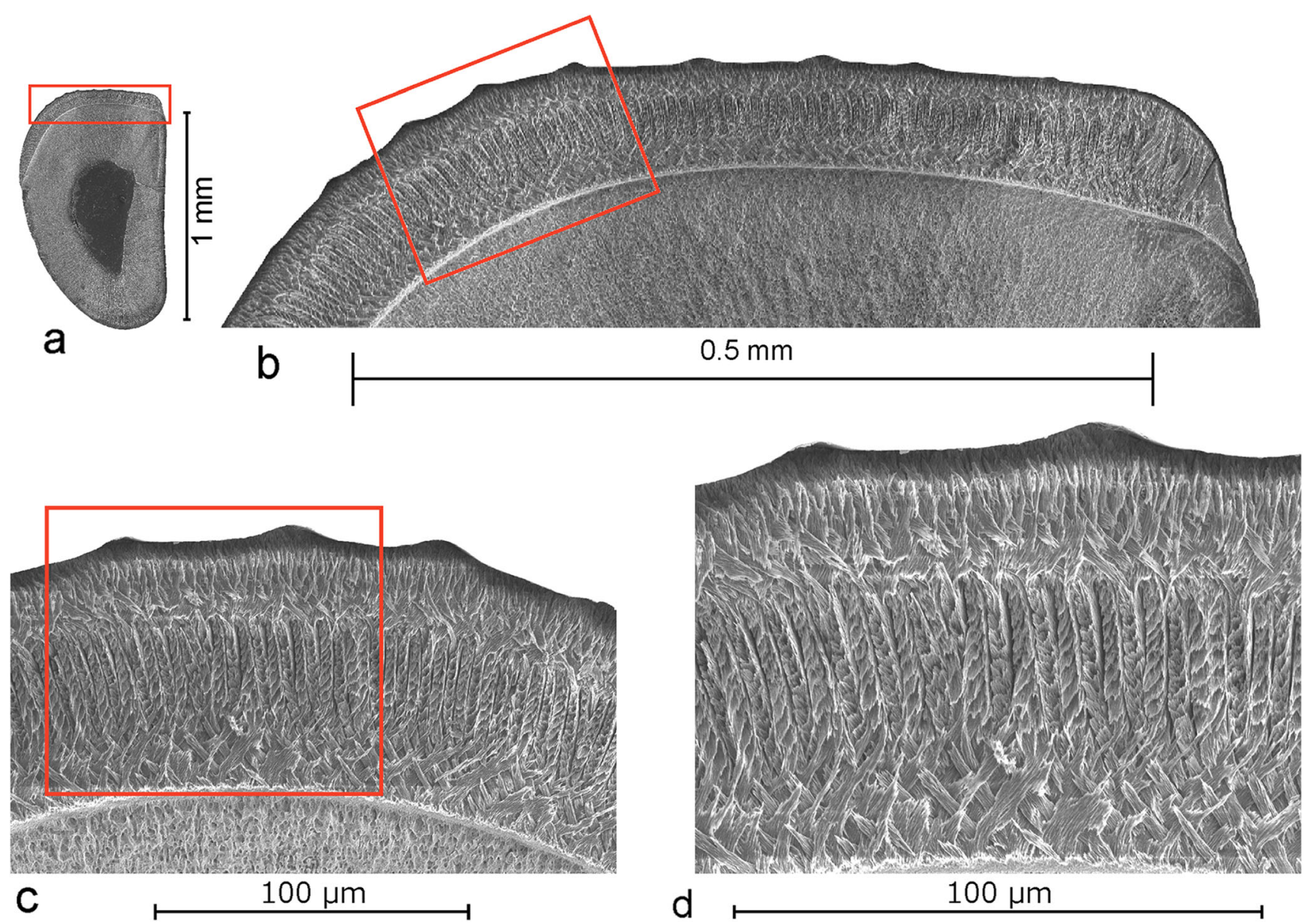

Fig. 10 The lower incisor of Paracricetodon stojanovici nov. sp. from Buštranje. Shown are a transverse section, b detail showing the external surface with ridges, $\mathbf{c}$ detail of $\mathbf{b}, \mathbf{d}$ detail of $\mathbf{c}$ 
Adrover (1989-1990). The HSB are longitudinally oriented. The transverse section shows that the basal part of the PI consists of a thin layer of enamel with the IPM at an angle to the prisms and a much thicker upper part with prism parallel IPM. The relatively thin PE consists of an internal layer of tangential enamel and an external layer of radial enamel (Fig. 10c, d).

The occurrence of this very derived schmelzmuster in the presumably late Eocene locality Buštranje shows that the major radiation that led to the diversity of the Oligocene Muridae dates at least back to the middle Eocene.

\section{Biostratigraphy}

The paracricetodontines do not provide much information on the age of the Serbian localities, because two of the three species described above are not known from elsewhere and the stratigraphical range of Paracricetodon dehmi, originally from Bernloch, a locality correlated with MP 25, is not known. $P$. stojanovici is very similar to $P$. wentgesi from Süngülü, a locality which is supposed to have an age around the EoceneOligocene boundary. However, our species, which has presumably a similar age has a more reduced $\mathrm{M} 3 / \mathrm{m} 3$ and is slightly smaller. Differences that may be due to adaptations to different ecological niches rather than due to difference in age.

\section{Conclusions}

Paracricetodon is present with about $10 \%$ in the late Eocene rodent fauna of Buštranje, is common (30-70\%) in the early Oligocene rodent faunas of Strelac, Raljin and Valniš. The rodent assemblages from Valniš and Strelac-3 contain three species of Paracricetodon. The assemblage from Strelac-1 shares two of these and further contains one $\mathrm{m} 3$ that possibly represents the genus Trakymys. Such a diversity of species and abundance of specimens of paracricetodontines is not known from elsewhere and suggests that the group underwent radiation on the Serbo-Macedonian land area. The new species Paracricetodon stojanovici is described from Buštranje and P. gracilis from Valniš. Paracricetodon stojanovici, a common constituent in its type locality, is also present in the collections from the younger localities Valniš, Strelac-1, -2, -3 and Raljin, while the rare $P$. dehmi occurs in Valniš and Strelac-1 and $P$. gracilis has been found in Valniš and Strelac-3 only.

A review of Paracricetodon species suggests that the hitherto formally described species $P$. spectabilis, $P$. cadurcensis, P. dehmi, $P$. walgeri and $P$. wentgesi are primarily distinct in size. If the upper dentition of the inadequately known P. spectabilis figured in Schaub (1925) and Stehlin and Schaub (1951) will appear to be a modal specimen, this species is not only the largest, but also the only Paracricetodon species with an M3 that is almost the same length as the M2. Paracricetodon kodjayarmensis and $P$. kavakderensis are considered to be junior synonyms of $P$. dehmi and P. confluens is considered a "Nomen Dubium".

The late Eocene newly described Paracricetodon stojanovici has very derived email pattern in its lower incisor showing that the major radiation that led to the generic diversity of the Oligocene Muridae dates at least back to the middle Eocene.

Acknowledgements We thank the Natural History Museum in Belgrade, the Ministry of Culture of the Republic of Serbia and the faculty of Earth Sciences of Utrecht University for support and hospitality. We are very grateful to Miloš Milivojević (NHMB) for his dedicated work in the field and laboratory. The help of our colleagues Loïc Costeur (Basel), Kurt Heissig and Gertrud Rössner (München) and Jerôme Prieto (Tübingen), who supplied data on Paracricetodon specimens under their care, is much appreciated. We thank Daniella Kalthoff (Oslo) for her expert counsel with the interpretation of the images of the enamel microstructure. The SEM images of the cheek teeth and the incisor enamel were made by Tilly Bouten and Hans Meeldijk (Utrecht University). Last, but not least we thank Mile Ilić for hospitality at the premises of the old watermill in Ljuberadja and Jovan Stojanović and the staff of motel Nina in Babušnica for their care. The constructive comments of the reviewers Marguerite Hugueney and Lutz Maul improved the paper and are highly appreciated.

Funding information The financial support for field work in Serbia received from the "Hans de Bruijn Foundation" contributed essentially to our success.

\section{Compliance with ethical standards}

Conflict of interest The authors declare that they have no conflict of interest.

Open Access This article is distributed under the terms of the Creative Commons Attribution 4.0 International License (http:// creativecommons.org/licenses/by/4.0/), which permits unrestricted use, distribution, and reproduction in any medium, provided you give appropriate credit to the original author(s) and the source, provide a link to the Creative Commons license, and indicate if changes were made.

\section{References}

Bahlo, E. (1975). Die Nagetierfauna von Heimersheim bei Alzey (Rheinhessen, Westdeutschland) aus dem Grenzbereich Mittel-/ Oberoligozän und ihre stratigrafische Stellung. Abhandlungen Hessisches Landesamt für Bodenforschung, 71, 1-182.

Bruijn, H. de, Marković, Z., Wessels, W., Milivojević, M., \& van de Weerd, A. A. (in press). Rodent faunas from the Paleogene of south-east Serbia. Palaeobiodiversity and Palaeoenvironments. https://doi.org/10.1007/s12549-017-0305-0.

Bruijn, H. de, Ünay, E., Saraç, G., \& Yilmaz, A. (2003). A rodent assemblage from the Eo/Oligocene boundary interval near Süngülü, Lesser Caucasus, Turkey. In N. López-Martínez, P. PeláezCampomanes, \& M. Hernández Fernández (Eds.), En torno a Fósiles de Mamíferos: Datación, Evolución y Paleoaimbiente. 
Coloquios de Paleontología, Volumen Extraordinario no 1. En honor al dr. Remmert Daams, 47-76.

Doukas, C. S., \& Theocharopoulos, C. D. (1999). Smaller mammals from the Oligocene of Kyprinos (Thrace, N. Greece). In J.W.F. Reumer, \& J. de Vos (Eds.), Elephants have a snorkel! Papers in honour of Paul Y. Sondaar. Deinsea, 7, 133-145.

Freudenthal, M., Lacomba, J. L., \& Sacristan, M. A. (1992). Classification of European Oligocene Cricetids. Revista Española de Paleontologia, Extra Volume, 49-57.

Hrubesch, K. (1957). Zahnstudien an tertiären Rodentia als Beitrag zu deren Stammesgeschichte: Über die Evolution der Melissiodontidae, eine Revision der Gattung Melissiodon. Abhandlungen der Bayerische Akademie der Wissenschaften, MathematischNaturwissenschaftliche Klasse, Neue Folge, 83, 1-100.

Hugueney, M., \& Adrover, R. (1989-1990). Rongeurs (Rodentia, Mammalia) de l'Oligocène de Sineu (Baleares, Espagne). Paleontologia I Evolució, 23, 157-169.

Illiger, C. (1811). Prodromus systematis mammalium et avium additis terminis zoographicis utriudque classis (pp. 1-301). Berlin: C. Salfeld.

Kalthoff, D. C. (2000). Die Schmelzmikrostructur in den Incisiven der hamsterartigen Nagetiere und andere Myomorpha (Rodentia, Mammalia). Palaeontographica A, 259, 1-193.

Kalthoff, D. C. (2006). Incisor enamel microstructure and its implications to higher level systematics of Eurasian Oligocene and Early Miocene hamsters (Rodentia). Palaeontographica A, 277, 67-80.

Marković Z, Wessels, W., van de Weerd, A. A., \& Bruijn, H. de (in press). On a new Diatomyid (Rodentia, Mammalia) from the Paleogene of S. E. Serbia, the first record of the family in Europe. Palaeobiodiversity and Palaeoenvironments. https://doi.org/10. 1007/s12549-017-0301-4.

Martin, T. (1997). Incisor enamel microstructure and systematics in rodents. In W. von Koenigswald \& P. M. Sander (Eds.), Tooth enamel microstructure. Balkema (pp. 163-175). Brookfield: Rotterdam.
McKenna, M. C., \& Bell, S. K. (1997). Classification of mammals above the species level (pp. 1-631). New York: Columbia University Press.

Mein, P., \& Freudenthal, M. (1971). Une nouvelle classification des Cricetidae (Mammalia, Rodentia) du Tertiaire de l'Europe. Scripta Geologica, 2, 1-37.

Rémy, J.-A., Crochet, J.-Y., Sigé, B., Sudre, J., Bonis, L. De, , VianeyLiaud, M., Godinot, M., Hartenberger, J.-L., Lange-Badré, B., \& Comte, B. (1987). Biochronologie des phosphorites du Quercy: mise à jour des listes fauniques et nouveaux gisements de mammifères fossiles. Münchner Geowissenschaftliche Abhandlungen, 10, 169-188.

Schaub, S. (1920). Melissiodon n. gen., ein bisher übersehener oligozäner Muride. Senckenbergiana, 2, 43-47.

Schaub, S. (1925). Die Hamsterartigen Nagetiere des Tertiärs und ihre lebenden Verwandten. Abhandlungen der Schweizerischen Paläontologischen Gesellschaft, 45, 1-110.

Schlosser, M. (1884). Die Nager des Europäischen Tertiärs nebst Betrachtungen über die Organisation und die geschichtliche Entwicklung der Nager überhaupt. Palaeontographica, 31, 1-143.

Stehlin, H. G., \& Schaub, S. (1951). Die Trigonodontie der simplicidentaten Nager. Schweizerische Paläontologische Abhandlungen, 67, 1-385.

Ünay-Bayraktar, E. (1989). Rodents from the middle Oligocene of Turkish Thrace. Utrecht Micropaleontological Bulletins, Special Publications, 5, 1-119.

Vianey-Liaud, M., Comte, B., \& Leveque, F. (1995). Le Garouillas et les sites contemporains (Oligocene, MP 25) des phosphorites du Quercy (Lot, Tarn-et-Garonne, France) et leurs faunes de vertebrés. 13. Rongeurs. Palaeontographica, A 236, 257-326.

Wessels, W., Marković, Z., van de Weerd, A. A., \& Bruijn, H. de (in press). New Melissiodontinae (Mammalia, Rodentia) from the Paleogene of south-east Serbia. Palaeobiodiversity and Palaeoenvironments. https://doi.org/10.1007/s12549-017-0311-2. 